\title{
The Effect of TAUNIT Carbon Nanotubes on the Properties of Electroplating and Anodic Oxide Coatings
}

\author{
D.N. Simagin*, A.A. Gravin, V.Yu. Kulakov, Yu.V. Litovka, E.A. Dyakov \\ Department of Systems of Computer Aided Support for Decision Making, \\ Institute of Automatics and Information Technologies, \\ Tambov State Technical University, 1, Leningradskaya St., Tambov, 392000, Russian Federation \\ *Corresponding author. Tel.: 7 (4752) 6326 01.E-mail: nanotam@yandex.ru
}

\begin{abstract}
The properties of the coatings produced by electrodeposition from electrolytes containing TAUNIT carbon nanotubes have been studied. The technology of zinc depositing from electrolytes with nanocarbon additives to increase the resistance to corrosion has been developed. Due to the fact that carbon nanotubes appear to be additional crystallization centers, the crystal size of the coating is reduced. The potentiodynamic method for determining the corrosion rate shows that the corrosion rate decreases fourfold, provided the concentration of TAUNIT carbon nanotubes in the electrolyte is $100 \mathrm{mg} / \mathrm{l}$. It is suggested that the improved corrosion resistance is due to a change in the structure of zinc coating. It is found that anodic oxidation in electrolytes containing TAUNIT CNTs leads to a change in the morphology of coatings and improves heat-release properties in air. The effect of different concentrations of CNTs in silver plating electrolyte on the characteristics of coatings has been described. The study of nanomodified palladation electroplating has revealed the effect of different CNT concentrations in palladation electrolyte on the microstructure and mechanical properties of coatings.
\end{abstract}

\section{Keywords}

TAUNIT carbon nanotubes; zinc coatings; corrosion protection; anodizing; palladation; silver plating.

(c) D.N. Simagin, A.A. Gravin, V.Yu.Kulakov, Yu.V. Litovka, E.A. Dyakov, 2016

\section{Introduction}

In terms of the performance criteria of a product, there are three types of electrochemical coatings: protective, protective-decorative and functional ones. The first type of coatings is used to protect parts against corrosion in various media. The second type of coatings is needed for decorating the products while protecting them from corrosion. Functional coatings provide a product surface with special properties, such as conductivity, hardness, wear-resistance, anti-friction and so on. Although modern technology sets the most demanding requirements for coating properties, conventional metal films of individual metals or their alloys do not usually meet these requirements [1-3]. To improve coating quality, nanomaterials, and, in particular, ultrafine diamonds are used [4-9]. According to a number of quality indexes, some progress has been made, however, there are some drawbacks, in particular, high cost of technology due to the high concentration of ultra-dispersed materials in electroplating electrolytes. Moreover, the quality of coatings does not meet the requirements of consumers.

The objective of the present study is to improve quality indexes of electroplating and anodic oxide coatings deposited from electrolytes containing TAUNIT carbon nanotubes.

\section{Experimental}

\subsection{Carbon nanotubes}

TAUNIT carbon nanotubes (CNTs) are long hollow fibers consisting of graphene layers having a fullerene-like structure. The number of graphene layers is no more than 30 , the diameter is from 10 to 60 nanometers, the internal diameter is $10-20 \mathrm{~nm}$; the length is $0.1-2 \mathrm{~mm}$; the bulk density is $0.4-0.5 \mathrm{~g} / \mathrm{m}^{3}$; the specific surface area is over $120 \mathrm{~m}^{2} / \mathrm{g}$; the thermal stability is up to $700^{\circ} \mathrm{C}$; 


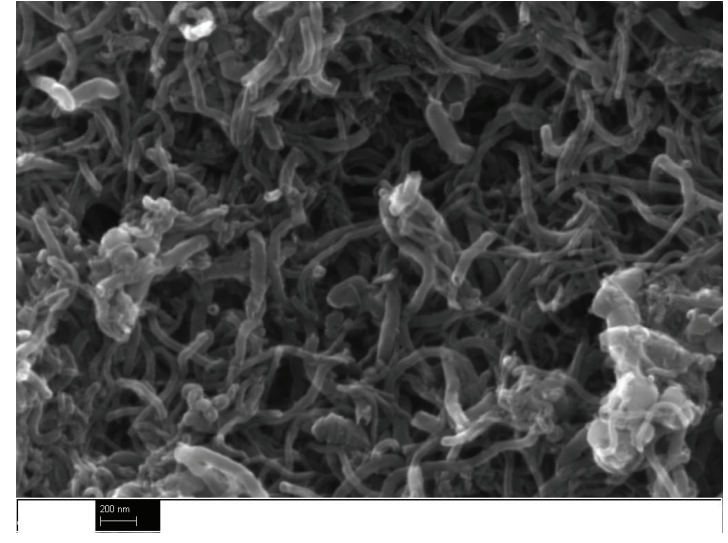

Fig. 1.TAUNIT CNM carbon nanotubes (a 5000-fold magnification)

the average pore volume is $0.22 \mathrm{~cm}^{3} / \mathrm{g}$; the mean pore size is $70 \mathrm{~A}$; the average thermal conductivity is $2000 \mathrm{~W} /(\mathrm{m} \cdot \mathrm{K})$ [10]. The amount of structured carbon should not be less than $95 \%$.

The photo taken by an NT MDT Integra Spectra atomic-force microscope (Fig. 1) shows TAUNIT carbon nanotubes produced at LLC "NanoTechCentre", Tambov.

\subsection{Processing and method for introducing TAUNIT in electrolytes}

To be used in the process of electrochemical deposition, TAUNIT carbon nanomaterial was subjected to multistage sieving and additional grinding in a cavitation mill. The purpose of these operations was to reduce the proportion of the agglomerated CNTs and prepare a product containing the largest amount of nanotubes with a length of no more than $100 \mathrm{~nm}$ and a diameter of no more than $70 \mathrm{~nm}$. In order to minimize aggregation of nanotubes, it was necessary to ensure their good medium wettability. This was achieved by dispersing CNTs in the medium. The studies have shown that ultrasonic dispersion can be considered the universal method for introducing CNTs in all the solutions of electrolytes [11, 12]. To introduced TAUNIT CNTs in electrolytes, an IL100 6/2 ultrasonic disperser was used. The equipment capacity was $2 \mathrm{~kW}$ at an operating frequency of $(22 \pm 10) \% \mathrm{kHz}$. The electrolyte was processed in portions of $100 \mathrm{ml}$ each, at an amplitude of a sound wave of $80 \mathrm{~mm}$ and the intensity of $786 \mathrm{~W} / \mathrm{cm}^{2}$. As a result, stable colloidal solutions of TAUNIT CNTs were produced both in acidic and alkaline electrolytes.

\subsection{Experimental technique}

Experimental studies were carried out for the following processes: zinc plating, anodizing, silver plating, palladation. In so doing different quality indexes that are important for each type of coatings were examined: for zinc coatings - corrosion resistance, for anode oxide coating of aluminum alloy heat-transfer properties, for silver and palladium coatings - roughness and microhardness.

In the experiments, a large number of samples having the same geometric characteristics and made of the same brand of metal were used as a substrate. To obtain one value of each quality index (corrosion resistance, microhardness, etc.) coatings were deposited, at least, on five samples. Only stable value samples were analyzed. The technology of zinc electrodeposition used in the experimental work corresponded to electrochemical zinc depositing on steel parts. The material used in samples was St3 steel.

Degreasing was performed at $75^{\circ} \mathrm{C}$ for $10 \mathrm{~min}$ in a solution composed of $10 \mathrm{~g} / 1$ sodium hydrate, $25 \mathrm{~g} / 1$ trisodium phosphate, $20 \mathrm{~g} / 1$ sodium carbonate, $20 \mathrm{~g} / 1$ liquid glass. After degreasing the sample was rinsed with warm water $\left(40-60^{\circ} \mathrm{C}\right)$ for $2 \mathrm{~min}$. Electrochemical degreasing was performed at $55^{\circ} \mathrm{C}$ for $10 \mathrm{~min}$ in a solution composed of $35 \mathrm{~g} / 1$ sodium hydrate, $55 \mathrm{~g} / 1$ trisodium phosphate, $25 \mathrm{~g} / 1$ sodium carbonate, $9 \mathrm{~g} / 1$ liquid glass, $1.5 \mathrm{~g} / 1 \mathrm{DS}-10$ synthanol. The current density was $5 \mathrm{~A} / \mathrm{dm}^{2}$. After electrochemical degreasing the sample was rinsed with warm water for 2 min and in cold water $\left(20-25^{\circ} \mathrm{C}\right)$ for $2 \mathrm{~min}$.

Etching was performed at $20^{\circ} \mathrm{C}$ for $5 \mathrm{~min}$ in a hydrochloric acid with a concentration of $75 \mathrm{~g} / \mathrm{l}$, followed by rinsing with cold water for $2 \mathrm{~min}$. Electrochemical removal of sludge was carried out at $25^{\circ} \mathrm{C}$, current density $D_{a}=5 \mathrm{~A} / \mathrm{dm}^{2}$ for $5 \mathrm{~min}$ in a solution of sodium hydroxide with a concentration of $125 \mathrm{~g} / \mathrm{l}$, followed by rinsing with cold water for $2 \mathrm{~min}$.

The composition of bright zinc plating electrolyte was the following: $115 \mathrm{~g} / 1$ sodium hydrate, $12 \mathrm{~g} / 1$ zinc oxide, $12 \mathrm{ml} / 1$ GE brightener. TAUNIT CNT concentrations in the experiments were $100 \mathrm{mg} / \mathrm{l}$; $200 \mathrm{mg} / 1 ; 400 \mathrm{mg} / \mathrm{l}$. The process was carried out at $20-23^{\circ} \mathrm{C}$ or $20 \mathrm{~min}$, at current density $D_{a}=0.5 \mathrm{~A} / \mathrm{dm}^{2}$. After bright zinc plating the sample was kept without current in the electrolyte for 30-60 s, rinsed with cold water for $2 \mathrm{~min}$ and dried at a temperature of $60-65^{\circ} \mathrm{C}$.

\section{Method for determining the throwing power}

To determine the throwing power, the equipment shown in Fig. 2 was assembled. The cathodes were placed in the grooves located in longitudinal walls of bath S. The distance between the anode and one of the cathodes was two times greater than the distance to the other cathode.

By the weight of zinc deposited on the near cathode $m_{n}$ and on the far cathode $m_{f}$, the throwing power $T$ of zinc plating electrolyte was calculated by formula: 


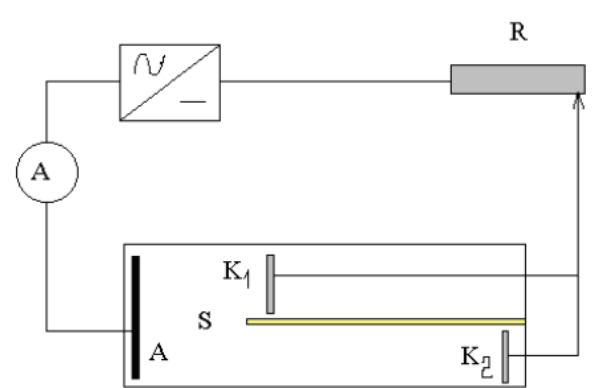

Fig. 2. The scheme of the equipment for determining the throwing power

$$
T=\frac{K-\frac{m_{n}}{m_{f}}}{K+\frac{m_{n}}{m_{f}}-2} 100 \%,
$$

where $K$ is the ratio of the distance between the far cathode $l_{f}$ and the near cathode $l_{n} ; l_{f}$ - the distance from the anode to the far cathode; $l_{n}$ - the distance from the anode to the near cathode.

\subsection{Anodic oxide coatings of aluminum alloys}

In the experimental work we used a standard technological cycle of anodizing aluminum and its alloys, comprising the following operations: degreasing, etching, lightening, anodizing, sealing and drying. In compliance with the State Standard GOST 9.305-84 of the Russian Federation, the samples were rinsed between processing operations.

Anodizing electrolyte was composed of: $200 \mathrm{~g} / 1$ sulfuric acid, $27 \mathrm{~g} / 1$ ECOMET-A200 composite, 100-1600 mg/l TAUNIT CNTs with an intermediate space of $100 \mathrm{mg} / \mathrm{l}$. The process temperature was $18-22^{\circ} \mathrm{C}$. The oxidation time was $20 \mathrm{~min}$. The current density was $D_{a}=1,5 \mathrm{~A} / \mathrm{dm}^{2}$. The samples made of $\mathrm{AMg}_{3}$ alloy had a diameter of $30 \mathrm{~mm}$ and a thickness of $2 \mathrm{~mm}$.

\section{Surface morphology}

Taking photos of the surfaces with side lighting confirmed the presence of conical protuberances. The difference between the morphology of the surfaces without an oxidized coating, the surfaces with a pure oxidized coating and the surfaces with nanomodified oxidized coating was revealed. Side lighting made it possible to confirm the presence of protuberances having a diameter of $4,11 \cdot 10^{-5}-5,88 \cdot 10^{-5} \mathrm{~m}$. The photos demonstrating a change in the surface morphology are given in Fig. 3.

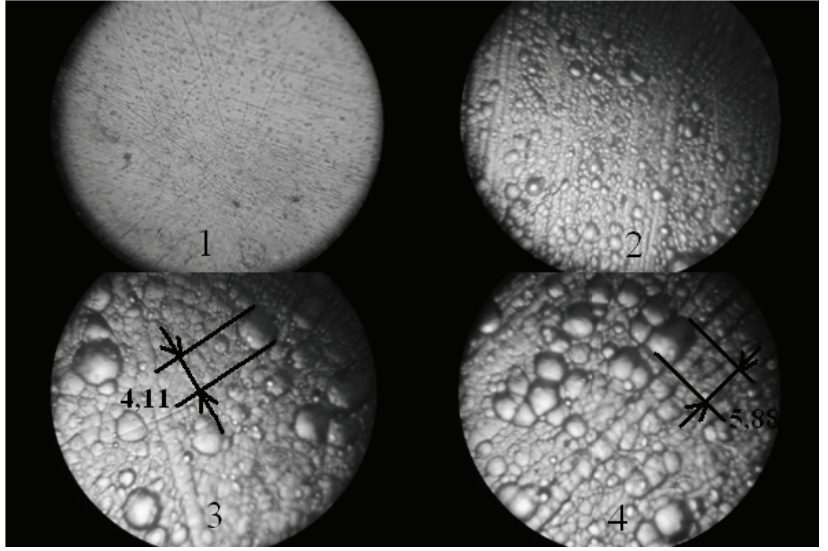

Fig. 3. The photos of the sample surfaces taken with a 850-fold magnification:

1 - without a coating; 2 - anodic oxide coating; 3 - anodic oxide coating with a concentration of $100 \mathrm{mg} / 1$ TAUNIT CNT in electrolyte; 4 - anodic oxide coating with the addition of $600 \mathrm{mg} / 1$ TAUNIT CNT in electrolyte

\subsection{Silver plating}

During silver plating experiments, copper samples with a working surface area of $4 \mathrm{~cm}^{2}$ were used. The technological process of silver plating of pure samples of coatings (without adding nanomaterials) was carried out in accordance with the classical scheme [14]. Sample preparation included degreasing in an organic solvent and drying; placing parts on a copper suspension and isolating; electrochemical degreasing; rising with warm running water; rinsing with cold running water; chemical activation; rinsing with cold running water.

Electrochemical silver plating was carried out by using an SG-07 electrolyte produced by ECOMET RPE (Moscow). It is a colorless transparent aqueous solution which includes a silver-containing compound. The electrolyte $\mathrm{pH}$ was 8.6-10.0. The density was $(1,11 \pm 0,02) \mathrm{kg} / \mathrm{m}^{3}$. The electrolyte was supplied ready for use. The anode was made of platinum.

To determine the parameters of roughness of silver coatings, a Veeco NT 9080 profilometer was used. The roughness was measured in the central part of samples on the three randomly selected $460 \times 615 \mathrm{~mm}$ areas. For each of them the map of the surface was constructed and the values of statistical characteristics were calculated - the arithmetic average surface roughness $R a$ and the root-mean-square roughness value $R q$.

A CARL ZEISS NEON 40 scanning electron microscope was used to study the porosity on a prepolished surface $(R q<100 \mathrm{~nm})$ of coating samples. SEM images were used to estimate the porosity. Pores with a size of $>0.5 \mathrm{~mm}$ were taken into account. 
According to SEM images the dependence of the surface pores concentration $C_{\mathrm{P}}$ on the CNM concentration in electrolyte was obtained.

The microhardness of silver coatings was measured in accordance with the State Standard GOST 21318-75 of the Russian Federation [2] by an G200 Nanoindentor using the method of scratching with a diamond indentor. A scratch was deposited by an angle of Berkovich diamond indentor having a radius of spherical tip bluntness of $20 \mathrm{~nm}$, at a constant scratching speed of $10 \mathrm{~mm} / \mathrm{s}$. Normal load on the indentor $P=15 \mathrm{mN}$ was chosen, provided the depth of a scratch was no more than $40 \%$ of the thickness of the silver coating surface. Over the entire length of a $500 \mathrm{~mm}$ scratch the normal load $P$ remained constant.

The microhardness of the material $H_{\nabla P}$ was calculated from the experimentally measured scratch width $b$. For metallic materials the microhardness predetermines the wear resistance - the higher is microhardness, the stronger is wear resistance. Accordingly, the smaller is a scratch width, the higher is the wear resistance of the material under the same normal loads $P[3]$.

\subsection{Palladation}

During plating experiments copper samples with an area of $1.5 \mathrm{~cm}^{2}$ were used. Sample preparation included such technological operations as degreasing in an alcohol-nefras mixture; drying; assembling; alkaline degreasing; rinsing with tap water; rinsing with distilled water; chemical activation; electrochemical copper plating; blasting; preliminary electrochemical silver plating; electrochemical cyanide silver plating.

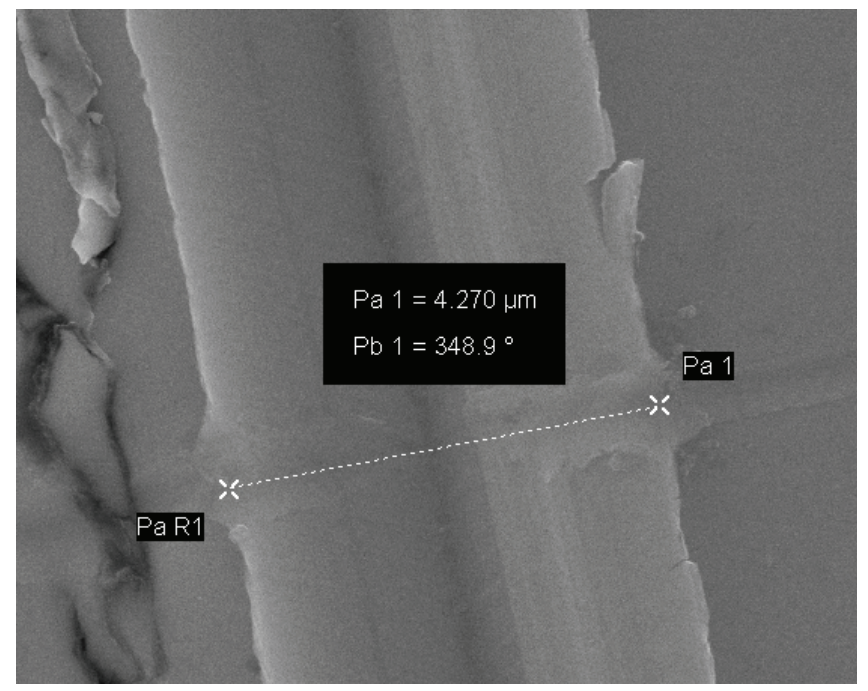

Fig. 4. The appearance of a scratch on the nanomodified palladium-plated coating
Electrochemical palladation was performed using electrolyte with $\mathrm{pH}=9,0-9,1$ composed of: 15-18 g/l chemically pure ammonium chloride, $25 \%$ aqueous ammonia, $0.1-0.2 \mathrm{~g} / 1$ protalbin acid. The anode was made of platinum (anode: cathode $=3: 1$ ).

To determine the effect of CNT concentration in electrolyte on the roughness of the obtained palladium plating, all the samples were examined on specialized equipment where they were subjected to brush wear, executing reciprocating movements over the coating surface. The wear testing of samples was performed for 1,5 and $10 \mathrm{~min}$, respectively. For measuring the roughness of the samples a Veeco NT 9080 profilometer was used. The roughness was measured in the central part of the samples in the three randomly selected $460 \times 615 \mathrm{~mm}$ areas. For each sample, the values of surface roughness height $R z$ at ten points and the mean square roughness $R q$ were obtained.

The microhardness of silver coatings was measured in accordance with the State Standard GOST21318-75 of the Russian Federation [2] by G200 Nanoindentor using the method of scratching with a diamond indentor. A scratch was deposited by the angle of Berkovich diamond indentor having a radius of spherical tip bluntness of $20 \mathrm{~nm}$, at a constant scratching speed of $10 \mathrm{~mm} / \mathrm{s}$. Fig. 4 shows the appearance of a scratch on a nanomodified palladium coating, prepared at a concentration of $\mathrm{CNTM}=$ $=45 \mathrm{mg} / \mathrm{l}$ in electrolyte. Normal load on the indentor $P=15 \mathrm{mN}$ was chosen provided the depth of a scratch was no more than $40 \%$ of the thickness of the silver coating surface. Over the entire length of a $500 \mathrm{~mm}$ scratch the normal load $P$ remained constant.

From the experimentally measured scratch width $b$ the microhardness of the material $H_{\nabla P}$ was calculated (Fig. 4).

\section{Results and Discussion}

\subsection{Corrosion resistance}

Corrosion resistance was studied using the potentiodynamic method with automatic potential sweep. Taking the polarization curves was carried out using a IPC-PRO potentiostat in the potentiodynamic mode in a three-electrode cell through PYREX glasses in $\mathrm{Na}_{2} \mathrm{SO}_{4}$ solution. The rate of application of the potential was $0.66 \mathrm{mV} / \mathrm{c}$. A saturated silver chloride electrode was used as a reference electrode, while a platinum one was used as an auxiliary electrode. The potentials were given by the normal hydrogen scale. The St3 steel electrode was used as a working one [13].

The introduction of $100-400 \mathrm{mg} / \mathrm{l}$ CNTs into a zinc plating electrolyte did not alter the corrosion potential of 


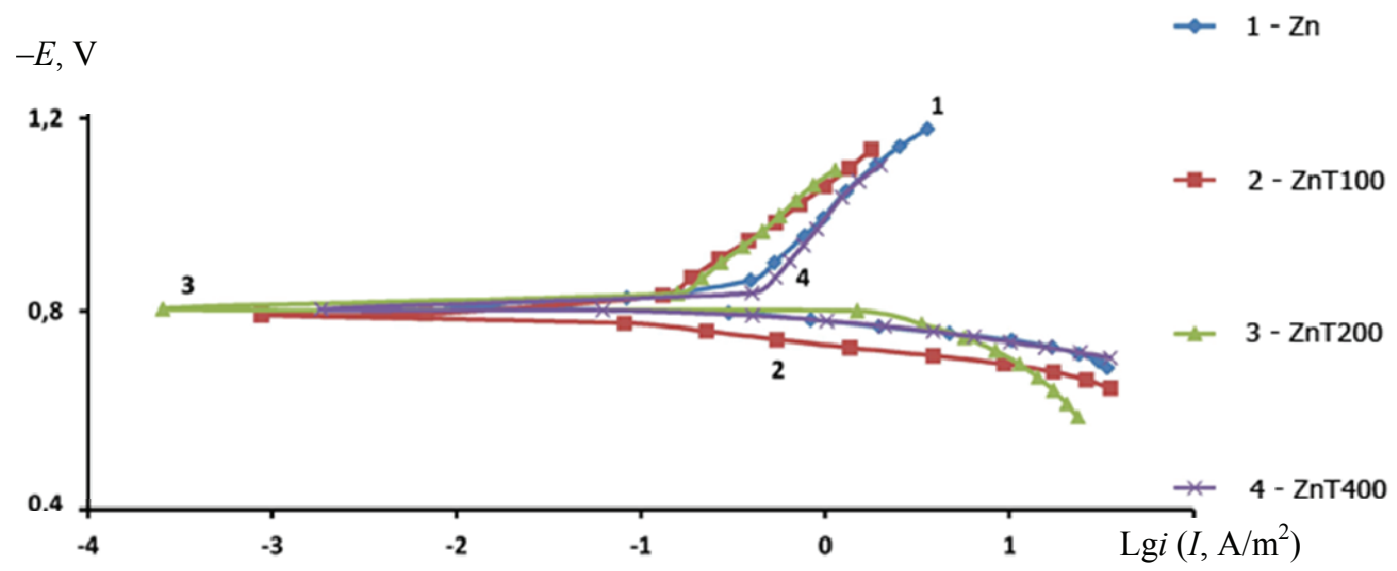

Fig. 5. Polarization curves for St3 steel samples with a pure zinc coating ( $\mathrm{Zn})$ and zinc coating with the addition of $100 \mathrm{mg} / \mathrm{l}$ TAUNIT CNT (ZnT100),

$200 \mathrm{mg} / \mathrm{l}$ TAUNIT CNT (ZnT200) and zinc coating with CNT concentration of $400 \mathrm{mg} / \mathrm{l}$ in the electrolyte (ZnT400)

a zinc coating, which was close to a normal one: $0.8 \mathrm{~V}$, which is typical of a compact zinc in neutral media (Fig. 5). The presence of $100 \mathrm{mg} / \mathrm{l}$ CNTs in the electrolyte inhibits the anodic reaction of zinc ionization and cathodic process of recovery of dissolved oxygen. The inhibition of the cathode process appeared to be more stable.

The analysis of polarization curves showed that the corrosion current of a zinc coating obtained in the presence of $100 \mathrm{mg} / \mathrm{l} \mathrm{CNTs}$ at a current density of $3 \mathrm{~A} / \mathrm{dm}^{2}$ in comparison with the coating obtained without adding CNTs is reduced by 4 times. The corrosion rate was estimated by the intersection of the cathode and anode polarization curves, rather than by the change in the rate of the cathode reaction. Since the point of intersection corresponds to a smaller corrosion current, proper conclusions were made. The nature of inhibition of the cathodic reaction is difficult to explain, but in the first approximation, it is caused by changes in the structure of the coating. Polarization measurements in chloride solutions have led to the same results [13].

In Fig. 6 you can see that the throwing power is increased by $7 \%$ at a concentration of $400 \mathrm{mg} / \mathrm{l}$ TAUNIT CNTs.

\section{Surface morphology}

In order to understand the cause of improving the corrosion resistance, the morphology of the coating was studied. The structure of the coating was examined using an NT MDT Integra Spectra atomicforce microscope. The nucleation of zinc crystals on the surface of nanotubes is shown in Fig. 7.

While depositing from the electrolyte, in which TAUNIT CNTs are distributed, the nanotubes are

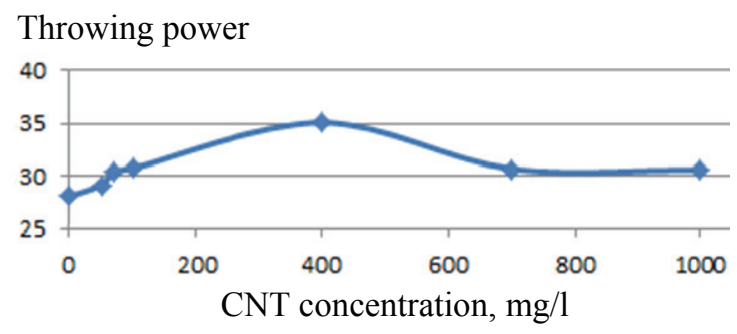

Fig. 6. The dependence of throwing power on TAUNIT CNT concentration

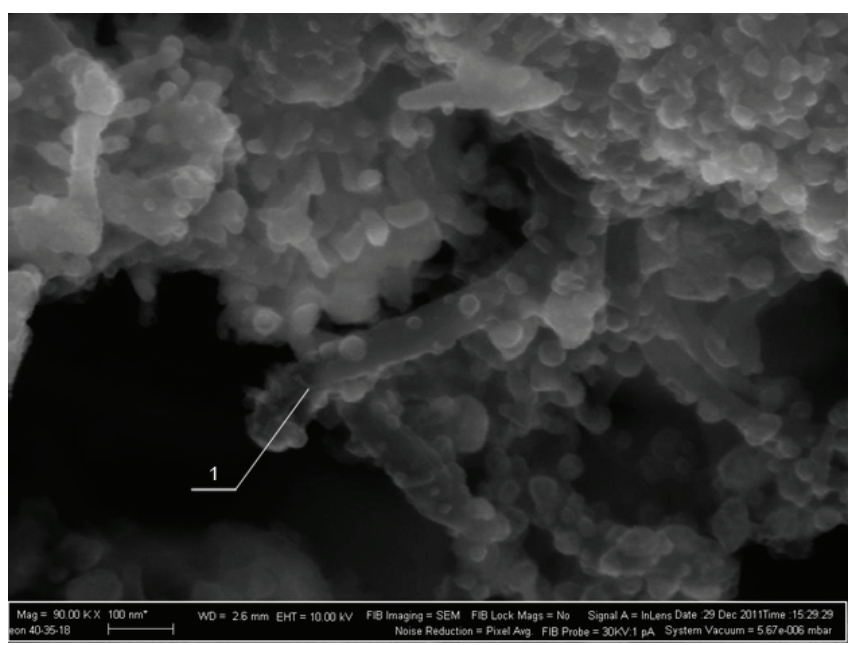

Fig. 7. Zinc crystal nucleation on CNTs: 1 - the crystals of zinc on carbon nanotubes (a 6000-fold magnification)

introduced into the coating. The fact that CNTs are additional crystallization centers results in the reduction of the crystal sizes of the coating. Fig. 8 shows the photographs of electrochemical zinc coating with a mesh spacing of $1 \mu \mathrm{m}$.

The change in coating morphology towards an increase in the density of zinc crystals arrangement and the porosity reduction, respectively, is obvious. 


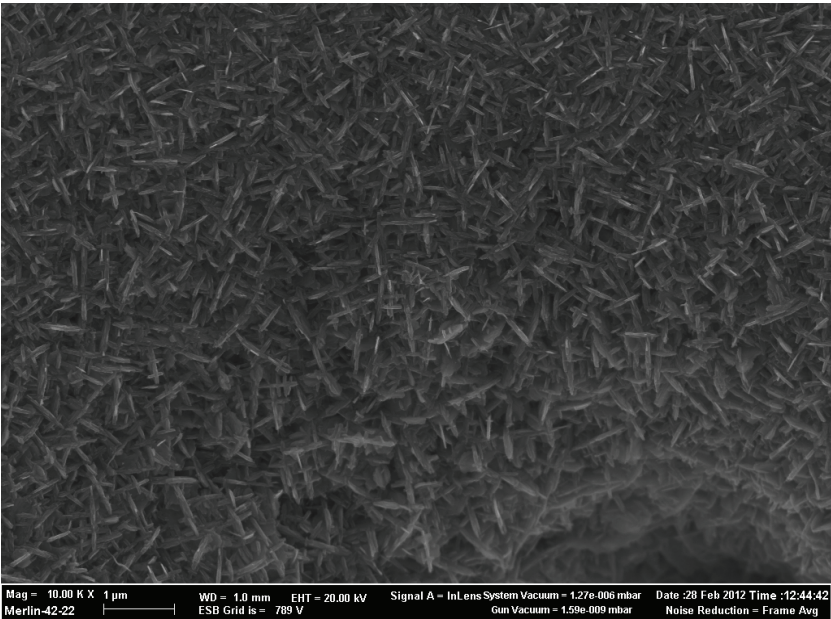

a)

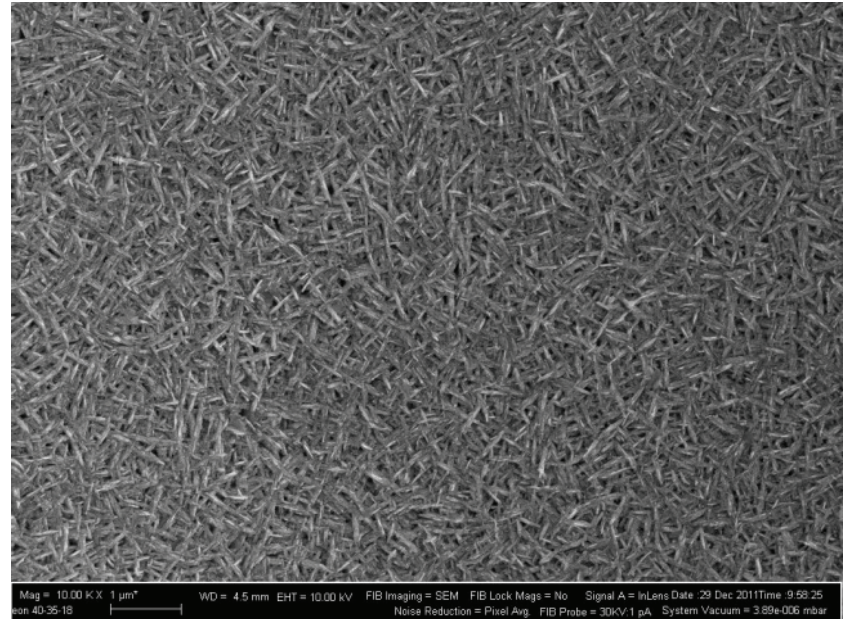

b)

Fig. 8. Zinc coating without CNTs $(a)$ and with CNTs $(b)$ (a 6000-fold magnification)

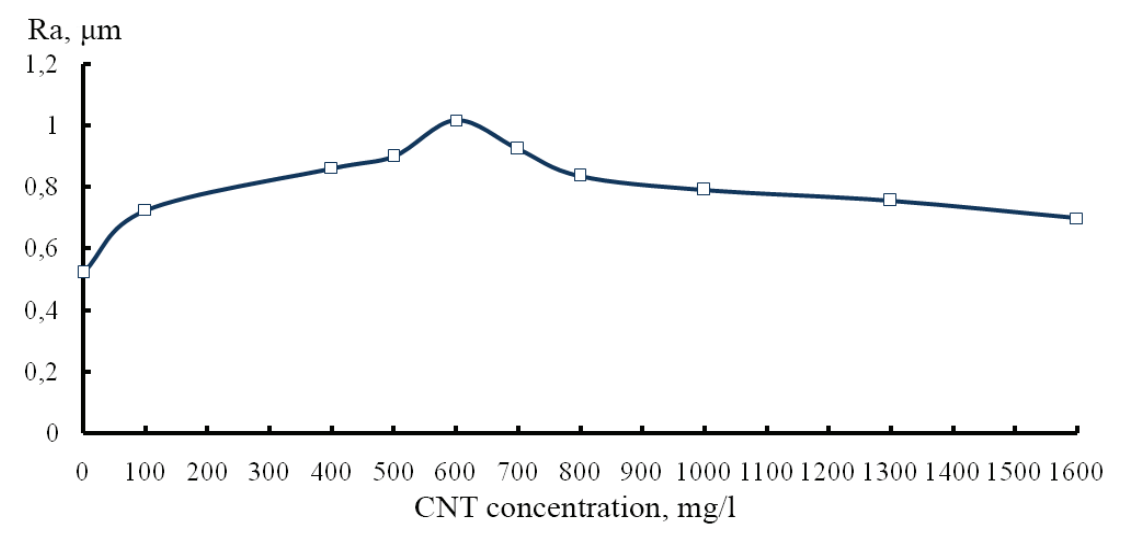

Fig. 9.The dependence of surface roughness parameter Ra of nanomaterial-modified electrochemical oxide coatings compared with unplated surfaces on the TAUNIT CNT concentration

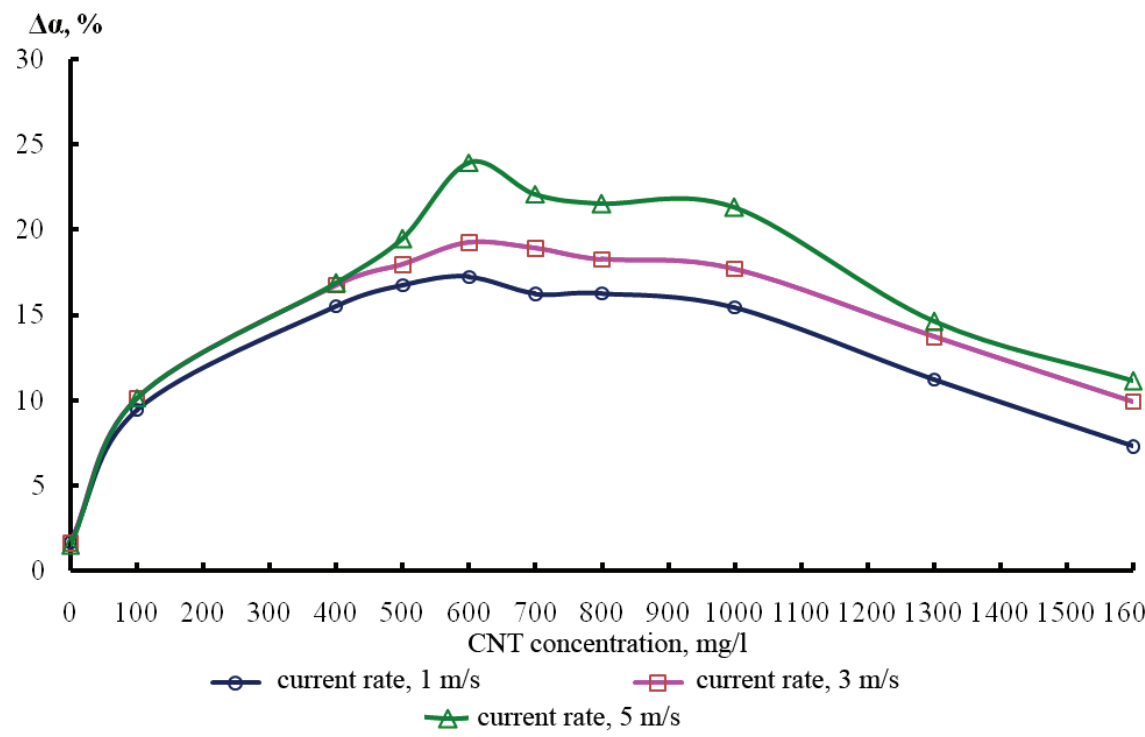

Fig. 10. The dependence of relative change in heat transfer coefficient from the surfaces with a nanomaterial-modified electrochemical oxide coating compared with unplated surfaces at different speeds air flow from the concentration of TAUNIT CNT

\subsection{Anodic oxide coatings of aluminum alloys}

\section{Coating roughness}

The arithmetic average surface roughness $R a$ increased by $107 \%$ on the surfaces with nanomaterialmodified electrochemical oxide coating by adding $600 \mathrm{mg} / \mathrm{l}$ TAUNIT CNTs to electrolyte (Fig. 9).

\section{Heat-release properties}

The best values of heat transfer coefficient in the air under forced convection were obtained at a concentration of $600 \mathrm{mg} / 1$ TAUNIT CNTs in the anodizing electrolyte. The heat transfer coefficient increased by 17,19 and $24 \%$ at air flow rates of 1,3 and $5 \mathrm{~m} / \mathrm{s}$, respectively (Fig. 10).

\section{Microhardness}

Microhardness $\mathrm{N} \mu$ of the obtained coating was measured by a PMT-3M device as described in [15] with a load of $50 \mathrm{~g}$. The microhardness of each sample was measured at 7 points, after which the results were averaged.

Fig. 11 shows that oxidation of a sample without adding TAUNIT nanomaterial to electrolyte increased 
the microhardness by $8 \%$. The best results were achieved when the concentration of TAUNIT nanomaterial added to electrolyte was of $10 \mathrm{mg} / \mathrm{l}$. This led to an increase in microhardness by $42 \%$ compared with an unplated sample and by $31 \%$ compared with an oxidized sample using a conventional electrolyte without adding TAUNIT nanomaterial.

\subsection{Silver Plating \\ Surface roughness}

Calculation results of roughness values are shown in Fig. 12.

Thus, the lowest roughness was achieved on silver coating samples deposited from electrolyte with the addition 60mg/1 CNM.

\section{Porosity}

There were completely no pores with size $>0.1 \mathrm{~mm}$ in the samples produced at a concentration of 40-80 mg/l (Fig.13).

\section{Microhardness}

Samples with the highest microhardness were produced at nanotube concentration $C_{\mathrm{CNM}}=40 \mathrm{mg} / \mathrm{l}$ (Fig. 13).

\section{Palladation}

\section{Coating roughness}

Measurement results are shown in Table. 1.

Thus, the lowest roughness is achieved on coating samples obtained at $C_{\mathrm{CNM}}=45 \mathrm{mg} / 1$ in electrolyte.

\section{Microhardness}

The highest microhardness of the coating is achieved on samples produced at a CNM concentration $C_{\mathrm{CNM}}=45 \mathrm{mg} / 1$ in electrolyte.

\section{Conclusion}

1. The potentiodynamic method for determining the corrosion rate of zinc coatings shows that the corrosion rate is reduced by 4 times in the presence of TAUNIT CNTs at a concentration of $100 \mathrm{mg} / \mathrm{l}$ and

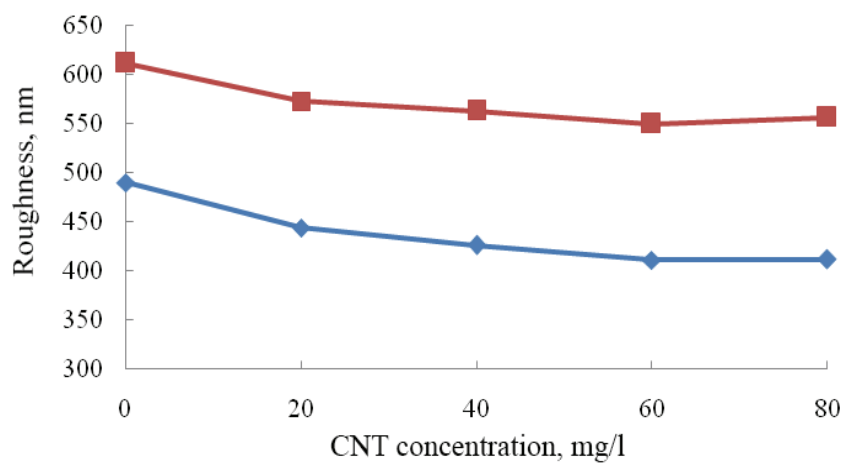

$\leadsto \mathrm{Ra} \rightarrow-\mathrm{Rq}$

Fig. 12. Surface roughness at different CNM concentrations in electrolyte

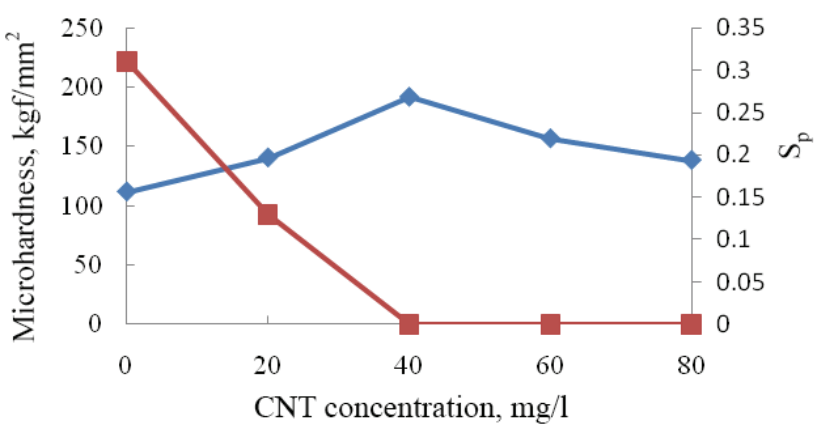

$\multimap$ Microhardness $\rightarrow$ Surface pore concentration

Fig. 13. Microhardness and surface pore concentration at different concentrations of CNM in electrolyte

Table 1

Palladium coating roughness at different wear time and CNM concentration in electrolyte

\begin{tabular}{lccc}
\hline \multirow{2}{*}{ CNM, mg/l } & \multicolumn{3}{c}{$R z / R q, \mathrm{~nm}$, at different wear time, min } \\
& 1 & 5 & 10 \\
\hline 0 & $1340 / 190$ & $1420 / 211$ & $1350 / 183$ \\
45 & $1380 / 181$ & $1180 / 181$ & $912 / 142$ \\
60 & $1190 / 184$ & $1230 / 207$ & $1090 / 146$ \\
70 & $1250 / 191$ & $1460 / 200$ & $1200 / 166$ \\
\hline
\end{tabular}


urrent density of $3 \mathrm{~A} / \mathrm{dm}^{2}$. Coatings containing TAUNIT CNTs have a fine-crystalline structure. The increase in corrosion resistance is due to a change in a sediment structure. The throwing power of the electrolyte has increased by $7 \%$ at a concentration of $400 \mathrm{mg} / \mathrm{l}$ TAUNIT CNT.

2. Anodic oxidation of $\mathrm{AMg}_{3}$ alloy in electrolytes containing TAUNIT CNTs leads to a change in the morphology of the coating and improves heat-release properties in air. Protuberances with a diameter from $4,11 \cdot 10^{-5}$ up to $5,88 \cdot 10^{-5} \mathrm{~m}$ appear on the surface at a concentration of $100 \mathrm{mg} / 1$ TAUNIT CNT. And at a concentration of $600 \mathrm{mg} / 1$ TAUNIT CNT heat-transfer coefficient in air under forced convection increases from 17 to $24 \%$. When the concentration of TAUNIT CNTs is $10 \mathrm{mg} / 1$, microhardness increases by $31 \%$.

3. The effect of different concentrations of CNTs in silvering electrolyte on the characteristics of coatings is revealed. The best results have been achieved on samples obtained at concentrations of 40 and $60 \mathrm{~m} / 1 \mathrm{CNT}$ in the electrolyte. Roughness for $R a$ is found to decrease by $16 \%$, for $R q-$ by $10 \%$. Pores with a size of $>0.1 \mathrm{~mm}$ at concentrations $40-80 \mathrm{mg} / 1$ are completely absent. The microhardness $H_{\nabla P}$ increased by $41 \%$.

4. The study of nanomodified palladium electriplating showed the effect of different concentrations of CNM in palladation electrolyte on the microstructure and mechanical properties of coatings. The best results were obtained for coatings with a concentration of $45 \mathrm{mg} / \mathrm{l} \mathrm{CNM}$ in electrolyte. Thus, roughness for $R z$ decreased by $18 \%$, for $R q$ - by $16 \%$. The microhardness increased by $26 \%$. Crystal size decreased by $20 \%$.

\section{Acknowledgement}

The work was performed as part of the program "START" supported by the "Foundation for Assistance to Small Innovative Enterprises in Science and Technology" (State Contract for R \& D: № 10334r/18346 of 04.06.2012 "The Development of Science-Based Techniques of Using Carbon Nanostructures for Producing Electrochemical Nano-Modified Zinc Electroplating Coatings with High Corrosion Resistance".

\section{References}

1. Elinek V.T. (2011). Galvanotehnika $i$ obrabotka poverhnosti [Electroplating and surface processing], 19(2), pp. 14-19. (Rus)

2. Kudryavtsev V.N., Okulov V.V. (2012). Sbornik prakticheskih materialov dlya rabotnikov galvanicheskih tsehov [Collected Materials for Electroplating workers]. Moskva: Globus. (Rus)

3. Fedosova N.L., Rumyantseva V.E., Rumyantseva K.E., Balmasov A.V., Chekunova M.D. (2009). Antikorrozionnaya zaschita metallov [Anticorrosion metal protection]. Ivanovo: Ivanovskiy gosudarstvennyiy arhitekturno-stroitelnyiy universitet. (Rus)

4. Yang Y.J. (2012). Bull. Mater. Sci.,35 (4), pp. 513-517.

5. Balasubramanian K., Burghard M. (2008). J. Mater. Chem.,18, pp.3071-3083.

6. Sheverdyaev O.N. (2009). Nanotehnologii $i$ nanomaterialyi.[Nanotechnologies and Nanomaterials]. Moskva: MGOU. (Rus)

7. Foster L. (2008). Nanotehnologii. Nauka, innovatsii $i$ vozmozhnosti [Nanotechnologies. Science, Innovations and Prospects]. Moskva: Tehnosfera. (Rus)

8. Solntsev Yu.P., Vologzhanina S.A., Pryahin E.I., Petkova A.P. (2009). Nanotehnologii i spetsialnyie materialyi [Nanotechnologies and Special Materials]. Moskva: Himizdat. (Rus)

9. Rambidi N.G., BerYozkin A.V. (2009). Fizicheskie $i$ himicheskie osnovy in nanotehnologiy [Physicaland Chemical Fundamentals of Nanotechnology]. Moskva: FIZMATLIT. (Rus)

10. Mishchenko S.V., Tkachyov A.G. (2008). Uglerodnyie nanomaterialyi. Proizvodstvo, svoystva, primenenie [Carbon Nanomaterials. Manufcature, Properties, Application]. Moskva: Mashinostroenie. (Rus)

11. Tkachyov A.G., Mischenko S.V., LitovkaYu.V., Dyakov I.A., Kuznetsova O.A., Tkachyov M.A. (2011). Sposob polucheniya nanomodifitsirovannogo galvanicheskogo nikelevogo pokryitiya [Method for Nanomodified Nikel Plating Depositing]. Patent RF № 2411309. (Rus)

12. Litovka Yu.V., Tkachyov A.G., Dyakov I.A., Kuznetsova O.A. (2011). Sposob polucheniya nanomodifitsirovannogo galvanicheskogo hromovogo pokryitiya [Method for Nanomodified Chrome Plating Depositing]. Patent RF № 2422562. (Rus)

13. Vigdorovich V.I., Shel N.V., Zarapina I.V (2012). Himiya. Ch. III. Osnovyi fizicheskoy himii. [Chemistry. Chapter 3. Fundamentals of Physical Chemistry], Tambov: Izdatelstvo Pershina R.V. (Rus)

14. Shluger M.A. (1985). Galvanicheskie pokryitiya v mashinostroenii. Spravochnik. Tom 1 [Electroplating in Mechanical Engineering]. M.: Mashinostroenie. (Rus)

15. Vyacheslavov P.M., Shmelyova N.M. (1977). Metody iispyitaniy elektroliticheskih pokryitiy [Methods of Testing Electrolyte Coatings]. M.: Mashinostroenie. (Rus) 